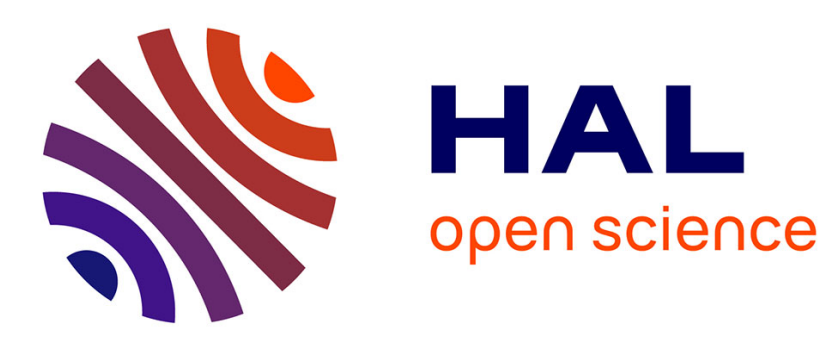

\title{
Two Lys-vasopressin-like peptides, EFLamide, and other phasmid neuropeptides
}

\author{
Jan A. Veenstra
}

\section{To cite this version:}

Jan A. Veenstra. Two Lys-vasopressin-like peptides, EFLamide, and other phasmid neuropeptides. General and Comparative Endocrinology, 2019, 278, pp.3 - 11. 10.1016/j.ygcen.2018.04.027 . hal03484378

\section{HAL Id: hal-03484378 \\ https://hal.science/hal-03484378}

Submitted on 21 Dec 2021

HAL is a multi-disciplinary open access archive for the deposit and dissemination of scientific research documents, whether they are published or not. The documents may come from teaching and research institutions in France or abroad, or from public or private research centers.
L'archive ouverte pluridisciplinaire HAL, est destinée au dépôt et à la diffusion de documents scientifiques de niveau recherche, publiés ou non, émanant des établissements d'enseignement et de recherche français ou étrangers, des laboratoires publics ou privés.

\section{다)(1) $(5$}

Distributed under a Creative Commons Attribution - NonCommercial| 4.0 International 


\title{
Temperature drop and gelatinization characteristics of waxy crude oil in $1000 \mathrm{~m}^{3}$ single and double-plate floating roof oil tanks during storage
}

\author{
Min Wang ${ }^{1}$, Xinyu Zhang ${ }^{2}$, Qianqian Shao ${ }^{3}$, Jingfa $\mathrm{Li}^{4}$, Bo Yu ${ }^{4 *}$ \\ ${ }^{1}$ Tianjin Research Institute for Water Transport Engineering, M.O.T., Tianjin 300456, China \\ ${ }^{2}$ Sinopec International Petroleum Exploration and Production Corporation, Beijing 100029, China \\ ${ }^{3}$ Guangdong University of Petrochemical Technology, Maoming 525000, China \\ ${ }^{4}$ School of Mechanical Engineering, Beijing Key Laboratory Pipeline Critical Technology and
}

Equipment for Deepwater Oil \& Gas Development, Beijing Institute of Petrochemical Technology, Beijing 102617, China

("Corresponding author: E-mail: yubobox@ vip.163.com)

\begin{abstract}
Single and double-plate floating roof oil tanks are two types of widely used floating roof oil tanks in petrochemical industry. However, the differences in flow and hear transfer characteristics of waxy crude oil inside these two tanks have been studied insufficiently. Finite volume method is employed in this research to study the temperature drop and gelatinization processes of waxy crude oil as well as the differences in single and double-plate floating roof tanks. Based on a comprehensive consideration of the atmosphere, soil, floating roof oil tank as well as the tank structure and the variations of the waxy crude oil state and rheological behavior, general physical and mathematical models are established. In the model, wax precipitation and gelatinization processes of waxy crude oil are described by the enthalpy-porous media method. Non-Newtonian behavior is described by the Power law equation. Turbulent natural convection is described by the LES method. SIMPLE algorithm is employed to couple pressure and velocity. Taking $1000 \mathrm{~m}^{3}$ single and double-plate floating roof oil tanks as examples, the evolution of oil temperature and flow behavior is studied and the variations of the gel oil thickness and heat flux are analyzed. Moreover, the differences between these two tanks are also discussed. Results show that due to the structure difference of the tank roof, the temperature drop rates are $0.018^{\circ} \mathrm{C} / \mathrm{h}$ and $0.007^{\circ} \mathrm{C} / \mathrm{h}$ respectively in single and double-plate floating roof tanks in the case of this research. Secondly, for the growth of gel oil on tank bottom, in double-plate floating roof tank, gel oil thickness keeps growing and fluctuating, while in single-plate tank, the original gelled oil layer disappears firstly and then increases gradually. Thirdly, although for both tanks, tank roof is the main part of heat dissipation towards the atmosphere, the maximum heat fluxes are respectively over $2.0 \mathrm{~kW}$ and $0.4 \mathrm{~kW}$ for single and double-plate floating roof tanks, and the total average heat fluxes respectively are $1.49 \mathrm{~kW}$ and $0.59 \mathrm{~kW}$.
\end{abstract}

Keywords: Single and double-plate floating roof oil tanks, Temperature drop, Wax precipitation and gelatinization, Non-Newtonian fluid, LES

\section{Introduction}

Almost $80 \%$ of crude oil produced in China is waxy crude oil which is characterized by high 
pour point, high viscosity and complex rheological property. Thus, in the practical production process, heating is always necessary. Single and double-plate floating roof oil tanks are the widely used oil tank in petrochemical industry. During storage, oil temperature drops due to the heat transfer between oil and environment. When oil temperature is below wax precipitation point, wax crystals start to precipitate in the oil. When wax precipitation amount reaches $1 \sim^{2 \%}{ }^{[1,2]}$ among the total, oil would gel, which seriously threatens the process safety and may even cause accidents. Therefore, it is of great significance to study the thermal and gelatinization characteristics in the single and double-plate floating roof oil tanks during storage.

There are two methods to study the characteristics of heat transfer of waxy crude oil in an oil tank: experimental study and numerical study. Due to its advantages in low cost, short research period and comprehensive research results, numerical simulation method is preferred by more and more researchers in recent years. Li et al. ${ }^{[3,4]}$ investigated the temperature drop process of crude oil in a $10 \times 10^{4} \mathrm{~m}^{3}$ double-plate floating roof tank using experimental and numerical simulation method. The effects of crude oil property, tank roof type, initial oil storage temperature, solar radiation and liquid level on oil temperature drop were analyzed and discussed. However, in this study, phase change and variation of rheological behavior of oil during wax precipitation were neglected and the results can be applied only to the temperature drop characteristics of crude oil with low wax content. Yang et al. ${ }^{[5]}$ adopted experimental method to study the characteristics of temperature drop in a $10 \times 10^{4} \mathrm{~m}^{3}$ floating roof tank in northeast China. The profiles of the oil temperature in the core region and along vertical direction in the tank were obtained and analyzed. However, in this research, the reason for temperature drop of oil in the tank was not investigated systematically. By considering the relationship between oil property and temperature, Zhao et al. ${ }^{[6,}$ ${ }^{7]}$ studied the gelatinization process of waxy crude oil in the floating roof tank. The gelatinization process of waxy crude oil was described with the classical phase change model proposed by Voller. However, during simulation, release of latent heat due to wax gelatinization was regarded as heat capacity at constant pressure. Moreover, during the study of the gel oil growth, natural convection was simplified into heat conduction. All these factors limit the application of the research results. Wang et al. ${ }^{[8]}$ applied numerical approach to study the temperature drop characteristics in a model tank which was geometrically similar to $10 \times 10^{4} \mathrm{~m}^{3}$ double-plate floating roof oil tank with the similarity ratio was 1:10. Furthermore, the effects of physical properties of waxy crude oil on the temperature drop process were analyzed. However, this research can only be applied to small-size floating roof tank. Besides, in this research, neither the increase of gel oil thickness nor the heat transfer process was analyzed. Wang et al. ${ }^{[9]}$ investigated heat transfer characteristics of waxy crude oil in a $10 \times 10^{4} \mathrm{~m}^{3}$ floating roof tank for long-term storage using both experiment and numerical simulation methods. On the aspect of experimental investigation, temperature drop processes of waxy crude oil at four different wax contents were analyzed, also the variation of vertical temperature distribution against time was obtained. On the aspect of numerical investigation, standard $k-\varepsilon$ model was applied to study the gelatinization process due to 
temperature drop, as well as the melting process due to temperature increase. However, the author still didn't analyze the gelatinization process of waxy crude oil deeply. Besides, the results of this research were only applicable to double-plate floating roof tank. Sun et al. ${ }^{[10]}$ carried out the numerical study on the flow and heat transfer characteristics of waxy crude oil in the cooling and heating processes during static tank storage, and the effects of the atmosphere temperature, solar radiation on the temperature field were analyzed. Results showed that the cooling and heating processes can be divided into several stages and each stage displays different characteristics. Moreover, solar radiation has great influence on the temperature fluctuation, and the atmosphere temperature has a great influence on the temperature drop rate. Oliveski et al. ${ }^{[1]}$ studied the temperature drop process in a small tank in $15 \mathrm{~h}$ using both numerical and experimental methods, in which the Ra numbers were fixed at $4.3 \times 10^{9}$ and $3.1 \times 10^{9}$ respectively. Oil temperature distribution along the tank height at the center of the tank was obtained and compared with the experimental results. The comparison showed that these results agree well with each other. Oliveski ${ }^{[12]}$ also studied the cooling process of the fluid with high Pr number fluid in tanks of different sizes using finite volume method. Correlations between the $\mathrm{Nu}$ number versus ratio of height to radius, dimensionless total heat transfer coefficient, Ra and Pr numbers were obtained. However, these researches focused on the small-size tank, without considering either phase change or non-Newtonian property of crude oil. Besides, variations of heat flux and gel oil growth during temperature drop were not involved. Some researchers ${ }^{[13-15]}$ also focused on small-size model tanks and simplified the turbulent natural convection into a laminar natural convection. Finite volume method was adopted to simulate the temperature drop process of crude oil numerically and the relationship between average oil temperature and storage time, oil level and tank radius, total heat transfer coefficient, Ra number, Pr number were fitted. However, due the too many assumptions and simplifications, the results are much different from the practice.

In conclusion, although there have been some researches on temperature drop process of waxy crude oil in floating roof tank, many shortcomings exist as well. (a) Previous researches usually treat oil state and rheological behavior change of waxy crude oil during temperature drop process as the change of physical property. Also, the interaction between wax crystals and liquid waxy crude oil are not considered accurately. (b) Previous researches commonly focus on double-plate floating roof tank while seldom on single-plate floating roof tank or compare both. (c) Previous researches make much effort in the study of temperature drop of waxy crude oil inside the tank, while systematic exploration on the mechanism of heat transfer and the growth of gel oil inside the tank is lacking. Therefore, in this study, with the consideration of the variations of oil state and rheological behavior, general physical and mathematical models of the temperature drop and gelatinization of waxy crude oil in single and double-plate floating roof oil tanks are established. $1000 \mathrm{~m}^{3}$ single and double-plate floating roof oil tank are taken as examples to study the characteristics of the temperature drop and gelatinization of waxy crude oil. The evolution of the gel oil thickness and heat flux are studied and analyzed in detail. Furthermore, the difference 
between single and double-plate floating roof oil tanks on the characteristics of heat transfer and gelatinization are also compared and analyzed systematically.

\section{Physical and mathematical models}

\subsection{Physical model}

The physical model of single and double-plate floating roof oil tanks contains the soil layer under the tank, air layer and steel layer in the tank roof (for single-plate floating roof oil tank, there is no air layer), waxy crude oil in the tank, steel layer on the tank bottom, steel layer and insulating layer on the tank wall. Thus, heat transfer in the tank involves the coupled heat transfer of gas-liquid-solid (for double-plate floating roof oil tank) or liquid-solid (for single-plate floating roof oil tank), heat conduction between tank and soil and forced convection between tank body and atmosphere. Predictably, heat transfer in both single and double-plate floating roof oil tanks is complex.

The state of wax crystal and waxy crude oil state varies depending upon oil temperature ${ }^{[16]}$. Specifically, at the initial moment, the oil temperature is relatively high and oil appears as pure liquid and shows Newtonian behavior. When oil temperature drops to below wax precipitation point $T_{w}$, wax crystals begin to precipitate and solid-liquid dispersion system begins to form. At this time, waxy crude oil still shows Newtonian behavior. When oil temperature continuously drops to below abnormal point $T_{a}$, waxy crude oil begins to show non-Newtonian behavior. At this stage, the solid-liquid dispersion system still exists. When oil temperature is below thixotropy appearance point $T_{t}$, wax crystals in the oil begin to cross-link with each other and form wax crystal porous media ${ }^{[16]}$, oil begin to gelate. Table 1 presents variations of the state of wax crystal and waxy crude oil and rheological behavior with oil temperature.

Table 1 Variations of the states of wax crystal and waxy crude oil, rheological behavior with oil

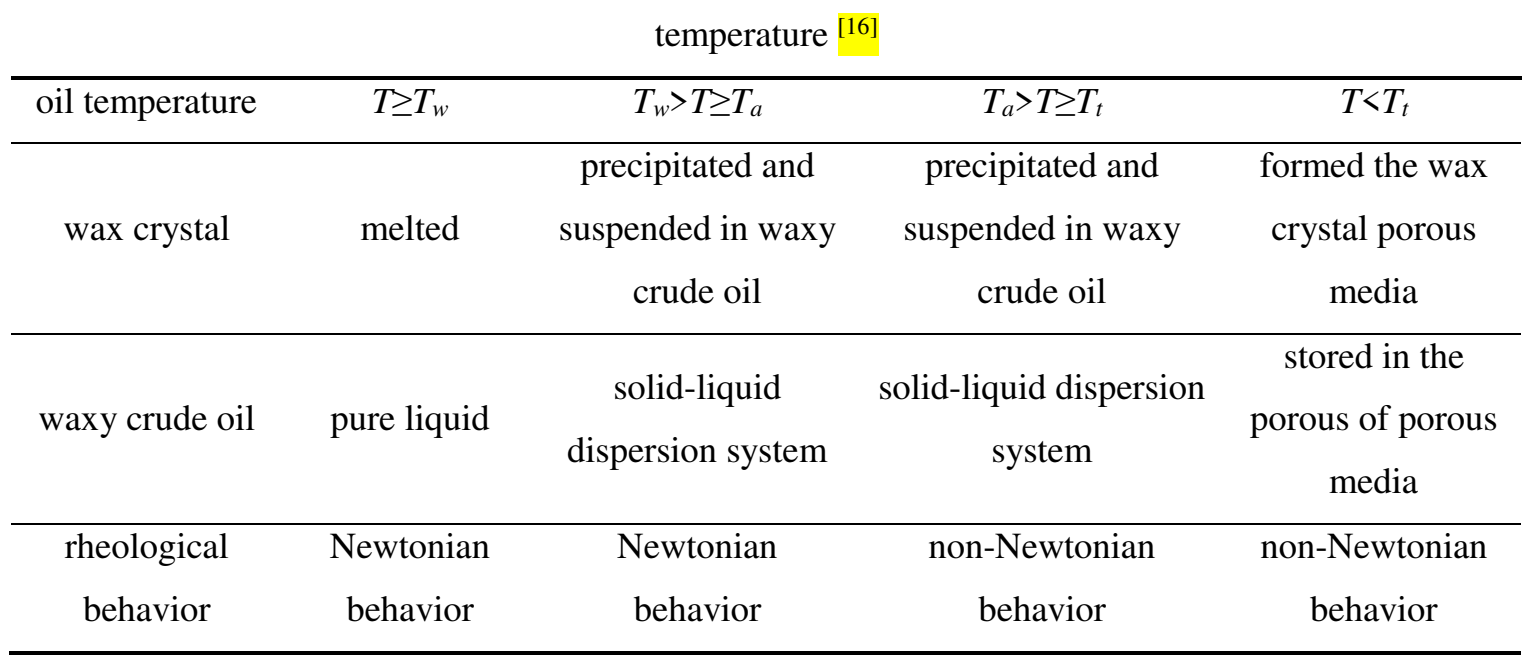

Furthermore, the size of the oil tank is large and the turbulent is violent. For instance, the radius of the $1000 \mathrm{~m}^{3}$ floating roof oil tank is $6 \mathrm{~m}^{[17,18]}$, and the Ra number reaches up to $2.0 \times 10^{13}$ 
when the temperature difference is $30^{\circ} \mathrm{C}$. Therefore, the computational burden and calculation time are unaffordable. Based on this, the actual floating roof oil tank is simplified into a 1rad one in this study with the consideration of the axisymmetric of the oil tank, as Fig. 1 shows.

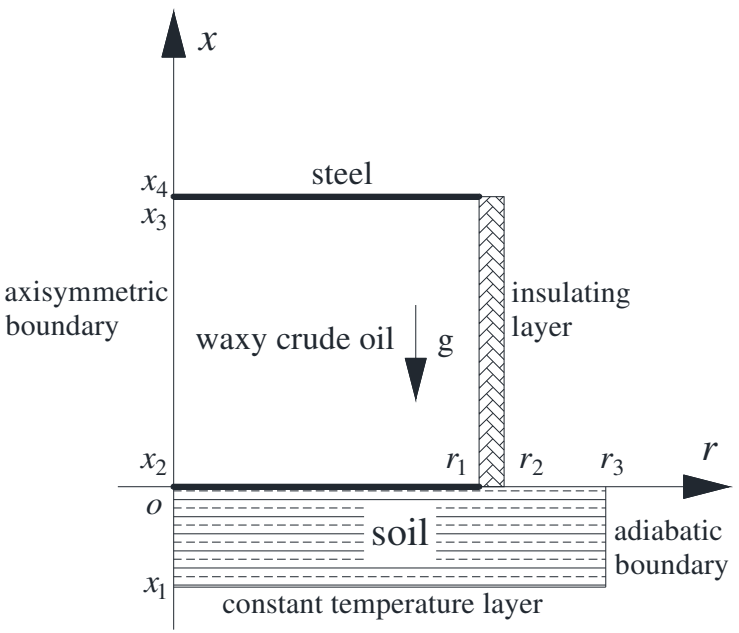

(a)

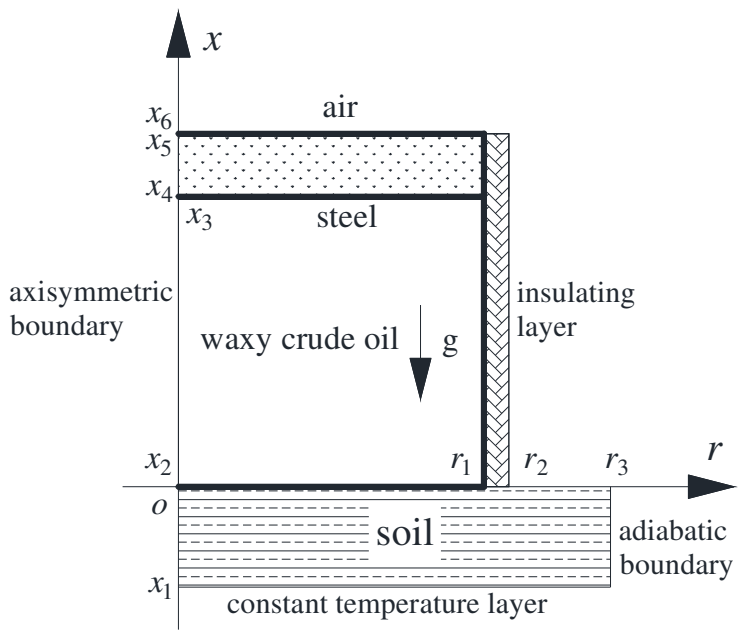

(b)

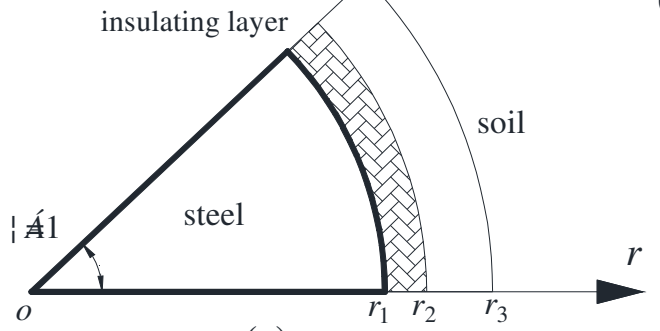

(c)

Fig. 1 Schematics of floating roof oil tank: (a) single-plate floating roof oil tank; (b) double-plate floating roof oil tank (front view); (c) floating roof oil tank (top view)

\subsection{Mathematical model}

General mathematical model of single and double-plate floating roof oil tanks is established within the two-dimensional cylindrical coordinate system involving the non-Newtonian behavior $[16,19,20]$ and wax precipitation (phase change) ${ }^{[21-26]}$. Considering the coupled gas-liquid-solid (double-plate floating roof oil tank) or liquid-solid (single-plate floating roof oil tank) heat transfer process in the tank, solid (steel layer, insulating layer) is particularly considered as fluid with infinite viscosity to realize an integration solving. Besides, LES method is adopted to calculate the turbulent flow and heat transfer of waxy crude oil in the tank.

The governing equations for the floating roof oil tank above the ground, which contains steel and air on tank top, waxy crude oil, steel on tank bottom and steel and insulating layer on tank wall, are shown in Eqs. (1) (5).

$$
\frac{\partial\left(\rho \bar{u}_{i}\right)}{\partial x_{i}}=0
$$




$$
\begin{gathered}
\frac{\partial\left(\rho \bar{u}_{i}\right)}{\partial t}+\frac{\partial\left(\rho \bar{u}_{i} \bar{u}_{j}\right)}{\partial x_{j}}=-\frac{\partial \bar{p}}{\partial x_{i}}+\frac{\partial}{\partial x_{j}}\left[\mu\left(\frac{\partial \bar{u}_{i}}{\partial x_{j}}+\frac{\partial \bar{u}_{j}}{\partial x_{i}}\right)\right]-\frac{\partial \tau_{i j}}{\partial x_{j}}+\rho g_{i}+s_{u i} \\
\frac{\partial\left(\rho c_{p} \bar{T}\right)}{\partial t}+\frac{\partial\left(\rho c_{p} \bar{u}_{i} \bar{T}\right)}{\partial x_{j}}=\frac{\partial}{\partial x_{j}}\left(\lambda \frac{\partial \bar{T}}{\partial x_{j}}\right)-\frac{\partial\left(c_{p} q_{j}\right)}{\partial x_{j}}+s_{h} \\
\tau_{i j}=\rho\left(\overline{u_{i} u_{j}}-\bar{u}_{i} \bar{u}_{j}\right) \\
q_{j}=\rho\left(\overline{u_{j} T}-\bar{u}_{j} \bar{T}\right)
\end{gathered}
$$

where, $\rho, \beta$ and $c_{p}$ are mass density, volume expansion coefficient and specific heat respectively. $\bar{u}_{i}, \bar{p}$ and $\bar{T}$ are the velocity, pressure and temperature after filter. $s_{u i}$ is source item caused by the binding effect of wax precipitation. $s_{h}$ is the source item of latent heat of wax precipitation, which will be discussed later. $\tau_{i j}$ and $q_{j}$ are the sub-grid scale stress tensor and sub-grid scale heat flux, which can be determined by Eqs.(6) and (7) ${ }^{[27-31] .}$

$$
\begin{gathered}
\tau_{i j}=-2 \mu_{t} \bar{S}_{i j}+\frac{1}{3} \delta_{i j} \tau_{k k} \\
q_{j}=-\frac{\mu_{t}}{\operatorname{Pr}_{t}} \frac{\partial \bar{T}}{\partial x_{j}}
\end{gathered}
$$

In Eqs. (6) and (7), $\bar{S}_{\bar{y}}$ is the rate-of-strain tensor for the resolved scale, which is calculated by $\bar{S}_{i j}=\frac{1}{2}\left(\frac{\partial \bar{u}_{i}}{\partial x_{j}}+\frac{\partial \bar{u}_{j}}{\partial x_{i}}\right)^{[27-31]} \cdot \mathrm{Pr}_{t}$ is sub-grid Prandtl number, which is fixed as $0.87^{[26,27]} \cdot \mu_{t}$ is sub-grid scale viscosity. The model of the SGS viscosity is critical for LES, and the Smagorinshy-Lilly model ${ }^{[26-29]}$ is applied in this research in order to account for the flow near the wall, as shown in Eq. (8).

$$
\mu_{t}=\rho L_{s}^{2}|\bar{S}|
$$

where, $L_{s}=\min \left(\kappa d, C_{s} \Delta\right){ }^{[26-29]} . \kappa$ is the von Karman constant and is taken as 0.41. $d$ is the distance to the closest wall. $C_{s}$ is the Smagorinsky constant. $\Delta$ is the filter width. $|\bar{S}|=\sqrt{2 \overline{S_{i j} \bar{S}_{i j}}}$.

On the other hand, governing equation for the heat conduction of soil under the tank is as following.

$$
\frac{\partial\left(\rho_{\text {soil }} c_{\text {soil }} T\right)}{\partial t}=\frac{\partial}{\partial x_{j}}\left(\lambda_{\text {soil }} \frac{\partial T}{\partial x_{j}}\right)
$$

\subsubsection{Rheological behavior}

When oil temperature is higher than abnormal point of waxy crude oil, the waxy crude oil shows Newtonian behavior. In this case, oil viscosity is only determined by oil temperature. On 
the other hand, when oil temperature is lower than abnormal point, oil acts as pseudoplastic fluid. The correlation between apparent viscosity and shear rate can be well described by the power law equation ${ }^{[16]}$. It is worth to mention that when the oil temperature drops below thixotropy appearance point $T_{t}$, the precipitated wax crystals cross-link with each other to form a wax crystal porous media with liquid waxy crude oil enwrapped in it. At this moment, the enwrapped liquid waxy crude oil is still pseudoplastic fluid and its rheological behavior can be described by the power law equation ${ }^{[16]}$.

Based on this, power law equation is adopted in this research to describe the non-Newtonian behavior of waxy crude oil, as shown in Eq. (10).

$$
\mu_{a}=K \dot{\gamma}^{n-1}
$$

where, $\ddot{\gamma}$ is shear rate, $\mathrm{s}^{-1} . K$ is consistency coefficient, $\mathrm{Pa} \cdot \mathrm{s}^{n} . n$ is flow behavior index.

\subsubsection{Wax precipitation and gelatinization}

When oil temperature is below wax precipitation point, wax crystals precipitate and suspend in the oil and flow with the oil. When oil temperature is below thixotropy appearance point, wax crystals in the oil cross-link with each other and form wax crystal porous media, which exerts binding effect on the oil. Furthermore, with the decrease of the oil temperature, porosity of the wax crystal porous media decreases gradually and the binding effect becomes stronger gradually ${ }^{[16]}$. The Darcy's law is adopted to describe this binding effect ${ }^{[21-25]}$, as Eq. (11) show.

$$
s_{u i}=-\frac{\mu}{K_{d}}\left(\bar{u}_{i}-\bar{u}_{i, s}\right)
$$

where, $u_{i}, u_{i, s}$ are the oil velocity and wax crystal velocity respectively. $K_{d}$ is the permeability of wax crystal porous media, which can be determined by the Kozeny-Carman equation ${ }^{[21-25]}$, as shown in Eq. (12).

$$
K_{d}=K_{0} \frac{\left(1-g_{s}\right)^{3}}{g_{s}^{2}}
$$

where, $K_{0}$ is the permeability constant and is set as $10^{-9}$ in this paper ${ }^{[22,23]} \cdot g_{s}$ is the amount of the wax precipitation.

Besides, latent heat would release during the temperature drop process. In this research, the released latent heat is characterized by the source item $s_{h}$ in energy equation.

$$
s_{h}=-\frac{\partial(\rho \Delta H)}{\partial t}
$$

where, $\Delta H$ is latent heat. In this paper, $\Delta H=\left(1-g_{s}\right) L$, where $L$ is the total phase change latent heat.

\subsection{Boundary and initial conditions}

\subsubsection{Boundary condition}

Boundary condition includes oil tank boundary condition and soil boundary condition. As to 


\section{Insulin 5}

Peruphasma-5 Spinotectarchus -5 clitarchus-5 Niveaphasma-5

Peruphasma-5 Spinotectarchus $=5$ Clitarchus-5 Niveaphasma-5

Spinotectarchus -6 Niveaphasma- 6 Clitarchus -6 Spinotectarchus- 6 Niveaphasma- 6 Clitarchus -6
1 MSTPLVQVIAVLIICIPTTTRTQ - -SSSAYQ̄NGKRSQACGKDLANMLQLVCGSRYNNLFKKSPPEEPRAEE 68 1 MTIACVQVIAVLIVCISTTTHAQSQSSTHQYGKRSQACGKDLANMLQLVCGSRYNNLFKKSPPEEPKAQE 70 1 MSTACVQVIAVLIVCISTITRA--QSSTHQHGKRSOACGKDLANMLQLVVGSRYNNLFKKSPPEEPKAEE 68 1 MSTACVQVIAVLIVCICTITHA - . QSSTHPYGKRSQACGKDLANMLQMVCGSRYNNLFKKSPPEEPKTEE 68

69 PYWLEPLPVADEPTTFPFRLTTEARSLIAḠSSRRLKRGLVDECCTKSCSIDEMRSYCAPP

71 PYWLEPLPVGDEPPFPFRVSSQARSLIPGAFRRLKRGLVDECCSKSCSIEEMRSYCAPP

69 PYWLEPLPVGGEPPFPFRVSSOARSLIPGAFRRLKRGLVDECCSKSCSIDEMRSYCAPP

69 PYWLEPLPVGGEPPFPFRVSSQARSLIPGAFRRLKRGLVDECCSKSCSIDEMRSYCAPP Insulin 6

1 MRCMAAVALVLLAAAGGTWAGPAPRCGRHLADLLAVVCKGHGYNNPLYHESSAPRRTRRGVVEECCKVSC 70

1 MRCMAAVALVLLAAAGGTWAKSAPRCGRHLADLLAVVCKGRGYNNPL HHESSAPARTRRGVVECCKVSC

1 MRCMAAVALVLLVAAGGTWAGPAPRCGRHLADLLAVVCKGRGYNNPLYHESSAPVRTRRGVVEECCKVSC

127

129

127

127

71 TFSTLQQYCKEPDTAHSHSRPAADVAGTKYKWVRHQDLPKKGRGRQHKKKGKRGNV

71 TFSTLRQYCKEPDTAQAHSRPAVDVAGTKYKRVRHQDLPKKGRGRQHKKKGKRGNA

71 TFSTLROYCKEPDTAQAHSRPAADVAGTKYKRVRHQDLPKKGRGROHKKKGKRGN-
70

126

126

125 


\section{Locusta}

Timema

Clitarchus

Ramulus

Peruphasma

Locusta

Timema

Clitarchus

Ramulus

Peruphasma
FLK - - - - - - TLSLLNERLSE - MQQSTTYN - DLVQFRVVRNLGSEFLGKRMENLGSEFLGKRM KEEQKRFLQKEGEQLQDEFSHLIYASNDKQTGSTGLRFKWIOLRSTRDLGSEFLGKRSKDFTRTLKPSNV TNKVRNSVQYRQSALFHEMADHYTGCCNMRMNWIPFRLARSLGSEFLGKRTT . . . . . . . . . . VASKLKTSGSYRHSGTSHAVADNDSGCCNMRLNWIQFRLARSLGSEFLGKRIS
- - - WIQLRLARSLGSEFLGKRTA -

\section{LKNILGVK}

FGKKHFAKALSLYRNISKSNIMFSKILYDLCGLNNFSKSDNKLKNIFKTLEVTEKRSLGSEFLGKRKPFK

- - - -

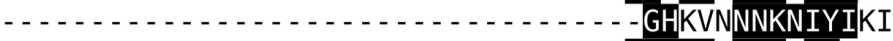
-FGHRDPNNKSIY - - - 
Tribolium

Zootermopsis Clitarchus - 1 Clitarchus -3 Clitarchus-2 Clitarchus-4 Clitarchus- 5

Tribolium

Zootermopsis Clitarchus - 1 Clitarchus- 3 Clitarchus - 2 Clitarchus - 4 Clitarchus -5

Tribolium Zootermopsis Clitarchus - 1 Clitarchus -3 Clitarchus - 2 Clitarchus-4 Clitarchus -5
- -MSTIITSIILLVLSESLVSGGCLITNCPRGGKRSKFAIS-ENAVKPCVSCGPGQS 53 - -MKMQLGTATLLAVFISLCTACLITNCPKGGKRAGTHSQELHTIRQCARCGPAKL 54 MQTSQLQSTVVVVVMVLSISSACLIVNCPKGGKRSLVHGK- -DALRQCPRCGPAKM 54 MKTSQILGTLFAMLVVVSTCSACLITNCPKGGKRSLGEGN - -DAPRQCPRCGPARA 54 MKTSQILGTLFAMLVVVSTCSACLITNCPKGGKRSLGEGN - - DAPRQCPRCGPART 54 - - - - - - - - MLVVVSTCSACLITNCPKGGKRSLDEGN - - DALRQCPRCGPART 42 MKTSQILGTLFAMLVVVSTCSACLITNCPKGGKRSLGEGN - -DAPRQCPRCGPART 54

GQCFGPSICCGP - FGCLVGTPETLRCQREGFFHEREPCIAGSAPCR-KNTGRCAFD 107 GHCYGPAICCGPQIGCLVATPDTARCLSEAASPVPCTAPTGAQCGEGKFAGRCTAN 110 GHCYGDNICCGVEIGCLVATPETLVCQRESMSPDPCVGPMGGVPCG - -SSGKCAAS 108 GHCYGADICCGVEMGCVMANVDTLVCQREQMSPEPCVGHTGHVPCG - -GNGKCAAA 108 GHCYGADICCGVEMGCMMATVDTLICQKEQMSPEPCVGPTGNVPCG - - GNGKCAAP 108 GHCYGADICCGVEMGCVMANVDTLVCQREQMSPEPCVGPTGNVPCG - - GNGKCAAP 96 GHCYGADICCGVEMGCVMANVDTLVCQREQMSPEPCVGPTGHVPCG - - GNGKCAAP 108

GICCSQDSCHADKSCASDDKSPIDLYTLINYQAELAGDK - . . . . . . . . . GVCCTHESCHIDITCQLTTSDAPELIDVSADQTNPLYSLYSSYQQENPGLGLSE GVCCTPDACMIDSACNQTPSQEMASMYLYS - AGNTRGVNQLSDVDDK - . - . . GVCCTPDSCTMDSSCHQPLSQEEENLVMYHNVGNMLVAGQLSDVDEK - . - . - . - . GVCCTPDSCTIDSSCHQPLSQEEANLLMYHNVGNMLGAGQLSDVDEK - . - . - . GVCCTPDSCTIDSSCHQPLSQEEANLLMYHNVGNMLGAGQLSDVYEK - . - . - . GVCCTPDSCTIDSSCHQPLSQEEANLLMYHNVGKMLGAGQLSDVDEK -

146 164 154 155 155 143 155 
Tribetile refrevetist prathath hrerduet Andorisiate Ratelet ketivikl topriasuar chirancer

frikelay hacrenosid heracharias irerivat

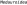
Cotelat ficylosdes Artatores? cilrancter

rrisida Facherecend Bernotyon Arstion Avilorerats Ant? cralolotes fetrignan cTirartat

tribetila

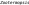
miartate Minda

Anlariside Conates loplaise triatshe cirarcet

trisely heorereces Neractiras incries Alowet out Oroling Ricrisises Setgisusen citrances

Treinelise Troberocts! Seracturas bostide

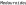
Ansto eiceloitos fataingas gifaribs Hes in:

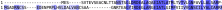

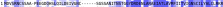

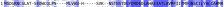

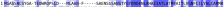

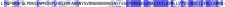

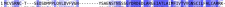

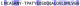

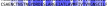
$\sin x$.

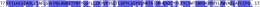

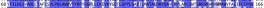

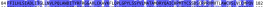

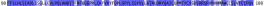

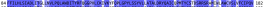

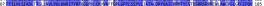

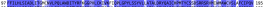
if

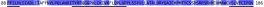

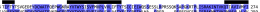

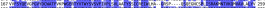

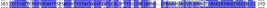

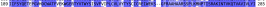

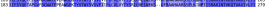

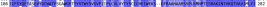

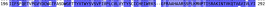

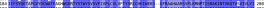

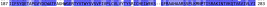

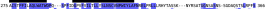

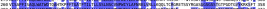

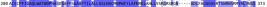

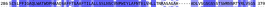

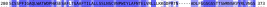
ald

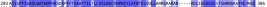

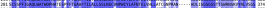

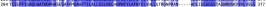

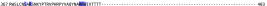

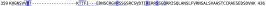
je IF

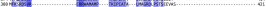

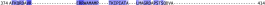

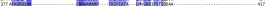

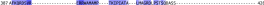

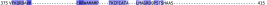

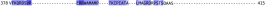

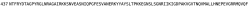

513 